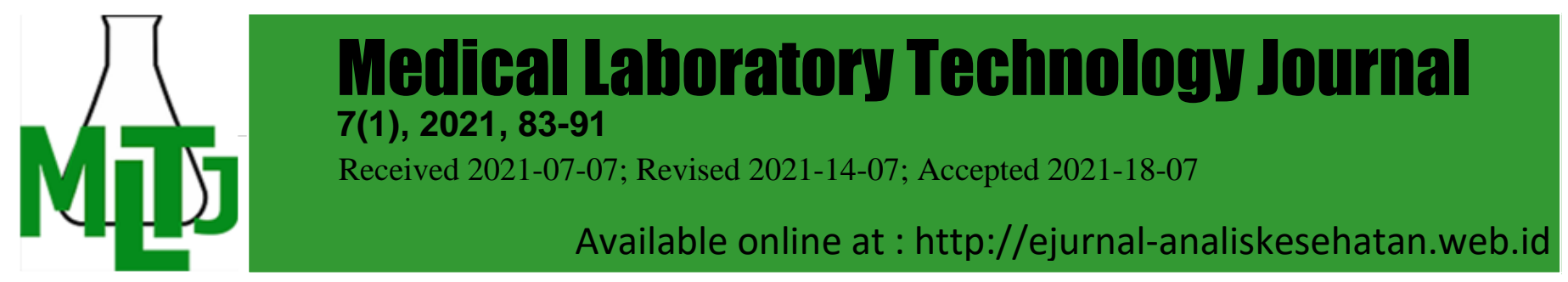

\title{
Invivo Effect Analysis of Rhodomyrtus tomentosa Leaf Ethanol Extract Against Escherichia coli
}

\section{Doris Noviani1, Adisty Dwi Treasa1, Ade Zakiya Tasman Munaf1, *Sri Winarsih², Dwi Yuni Nur Hidayati ${ }^{3}$, Mukhamad Nooryanto ${ }^{4}$, Sutrisno ${ }^{4}$}

\author{
${ }^{1}$ Master of Midwifery, Faculty of Medicine, Brawijaya University, Indonesia, \\ ${ }^{2}$ Department of Pharmacy, Faculty of Medicine, Brawijaya University, Indonesia, \\ ${ }^{3}$ Department of Microbiology, Faculty of Medicine, Brawijaya University, Indonesia, \\ ${ }^{4}$ Departement of Obstetric and Gynecology, Faculty of Medicine, Brawijaya \\ University, Indonesia. *Correspondence Email: wien23.fk@ub.ac.id
} DOI: $10.31964 / \mathrm{mltj} . v 7 i 1.392$

\begin{abstract}
Puerperium infection contributed 11 percent of 48.17 percent of maternal mortality during the puerperium period; one of the causes of increased risk of puerperium infection was bacteria Gram-negative Escherichia coli. Puerperium infection occurred because bacteria enter through the vagina, wounds on the insertion of the placenta, and other parts spread to blood throughout the body and damage the spleen, liver, and uterus. This research aimed to determine the effect of Rhodomyrtus tomentosa leaves ethanol extract (Rtl-EE) as an antibacterial on the spleen, liver, and uterus of Escherichia coli -induced puerperal infection model mice. Mice in the postnatal treatment group were induced by Escherichia coli bacteria intravaginally and given different doses of ethanol extract of Rhodomyrtus tomentosa leaves. Examination of bacterial colonies growth used pour plate method with EMBA media. The research results showed that the administration of Rtl-EE decreased the growth of bacterial colonies respectively in the liver $1280,924,330$ $\mathrm{CFU} / \mathrm{mL}$; the uterus $1806,1180,874 \mathrm{CFU} / \mathrm{mL}$; and the spleen $712,112,774 \mathrm{CFU} / \mathrm{mL}$. Colony growth started to decrease at dose 1 of Rtl-EE (100mg/kg BW) of mice model of Escherichia coli -induced puerperal infection. Rhodomyrtus tomentosa leaves contain active compounds - phenols, flavonoids, saponins, tannins, alkaloids, and triterpenoids as antibacterial. Rtl-EE had an antibacterial effect by reducing the number of bacteria on the spleen, liver, and uterus of Escherichia coli -induced puerperal infection model mice. Further research needs to conduct to examine the toxic dose of Rhodomyrtus tomentosa leaves against Escherichia coli bacteria.
\end{abstract}

Keywords: Rhodomyrtus tomentosa; puerperium infections; Escherichia coli

\section{INTRODUCTION}

Complication during the puerperium could increase maternal mortality; 50 percent of the risk of death increasing occurred in the first 24 hours postpartum (Wardhani et al., 2017). Puerperium infection contributed 11 percent of 48.17 percent of maternal mortality during the puerperium period (Haruna., 2017). During the puerperium period, wounds on the insertion of the placenta and other parts - cervix, vulva, vagina, and perineum could trigger penetration of bacteria. Bacteria spread throughout the body from the vagina because they apply through blood flows (Cunningham et al., 2010; Marni., 2012). Puerperium infection causes by one of the Gram-negative bacteria - Escherichia coli (Song et al., 2020). Escherichia coli is one of the most common organisms found in the genital tract as a reservoir for vaginal

Corresponding Author: Sri Winarsih

Department of Pharmacy - Faculty of Medicine, Brawijaya University

JI. Veteran, Ketawanggede, Kec. Lowokwaru, Kota Malang, Jawa Timur, Indonesia, 65145 Email: wien23.fk@ub.ac.id 
colonization resulting in urinary tract infections, chorioamnionitis, and puerperal infections. Immune system status and host susceptibility play an essential role in condition and disease growth. Escherichia coli strains can turn into virulent strains and resistance, which allow bacteria to enter the host cells and avoid defensive mechanisms that cause infection (Sáez-López et al., 2016). Moreover, Escherichia coli could cause damage to the spleen, liver, kidney, and uterus (Boushra and Rahman., 2020; Mochtar and Sofian., 2012). The treatment of Escherichia coli infection used antibiotics. However, the use of antibiotics can cause resistance, Escherichia coli bacteria become more resistant to several antibiotics such as spectinomycin (100\%), polymyxin B $\quad$ (97.6\%), levofloxacin (54.5\%), penicillin $G(100 \%)$, and erythromycin (88.9\%) (Hilda and Berliana., 2015). The research to obtain new and readily available antibacterial alternatives needs to conducts.

Rhodomyrtus tomentosa considers a weed or pest because it has a relatively high growth rate and is easy to find in North Kalimantan, especially in Tarakan (Ismandari et al., 2020). Rhodomyrtus tomentosaleaves people in Kalimantan traditional medicine to prevent postpartum infections (Harlia Erika Juniar., 2017). There was previous research that tested the effectiveness of this extract against Escherichia coli but only in vitro. Indriani et al. (2019) showed that the extract and ethanol fraction of karamunting (Rhodomyrtus tomentosa (Aiton) Hassk) leaves could inhibit the growth of Escherichia coli bacteria, with the best concentrations being $80 \%$ extract and $100 \%$ ethanol fraction with inhibition zones of $8.2400 \pm 1.18025$ and $8.7800 \pm 1.00100$, respectively. Sukeri et al. (2021) also investigated the antimicrobial activity of Methanolic and Aqueous extracts of Rhodomyrtus tomentosa leaves against Staphylococcus aureus and Escherichia coli. However, to the researcher's knowledge, the effect of this extract in vivo has never been studied before, so this research aimed to find out the effect of Rhodomyrtus tomentosa leaves ethanol extract (Rtl-EE) as an antibacterial on the spleen, liver, and uterus of Escherichia coli -induced puerperal infection model mice.

\section{MATERIALS AND METHOD}

\section{Rhodomyrtus tomentosa Leaves Ethanol Extract}

Rhodomyrtus tomentosa leaves were obtained in Tarakan, North Kalimantan, Indonesia. Rhodomyrtus tomentosa leaves were 48 hours-dried at $60^{\circ} \mathrm{C}$ in an oven and mashed in a blender. Rhodomyrtus tomentosa leaves powder extracted with $95 \%$ ethanol solvent for maceration. The extract was evaporated using a rotary evaporator and ensured no ethanol droplets were in the reservoir flask. Thick extract of Rhodomyrtus tomentosa leaves put in a bottle and stored at $4^{\circ} \mathrm{C}$ until use.

\section{Phytochemical analysis of Rhodomyrtus tomentosa leaves}

One gram of the plant ethanol extracts was dissolved in $100 \mathrm{~mL}$ ethanol and subjected to qualitative phytochemical screening following a previous method (Senthilmurugan et al., 2013).

\section{Experimental animals}

BALB/c mice (female, 14 days pregnant, weight 25-45 grams) reared in the Veterinary Laboratory, Faculty of Medicine, University of Brawijaya Malang, Indonesia. Mice were acclimatized for four days and randomized. Mice randomly assign to 5 research groups, 1 group consisting of 5 mice, namely negative control (K-), positive control $(\mathrm{K}+)$, and three treatment groups. Group $\mathrm{K}(-)$ is a group with healthy mice that not given Escherichia coli, or Rhodomyrtus tomentosa leaves ethanol extract, while group $\mathrm{K}(+)$ and three treatment groups (Rtl-EE I, Rtl-EE II, Rtl-EE III) others 
intravaginally induced by Escherichia coli at a dose of $1 \times 107 \mathrm{CFU} / \mathrm{mL}$. The treatment group (Rtl-EE I, Rtl-EE II, Rtl-EE III) give ethanol extract of Rhodomyrtus tomentosa leaves at a dose of $100 \mathrm{mg} / \mathrm{kg} \mathrm{BW}, 200 \mathrm{mg} / \mathrm{kg} \mathrm{BW}$, and $400 \mathrm{mg} / \mathrm{kg} B W$ once for one day.

\section{Procedure for preparing mice model of puerperal infection}

After the mice gave birth, Escherichia coli immediately injects an infection dose of $1 \times 107 \mathrm{CFU} / \mathrm{mL}$ of $0.2 \mathrm{~mL}$, which administer intravaginally using a $1 \mathrm{cc}$ syringe based on a previous study modified animal model Pascual et al., (2010). After that, it was waited for up to 2 hours to become a model of puerperal infection. Infected mice characterize by weakened movement, hair loss, and having excessive leukocyte count (5100-11600 cells/ $\mu$ l).

\section{Escherichia coli Culture and Bacterial Colony Examination}

Escherichia coli bacteria were taken from the patient's urine specimen stock at the Microbiology Laboratory, Faculty of Medicine, University of Brawijaya Malang, Indonesia. Escherichia coli cultures were placed at $40 \mathrm{C}$ for 24 hours in Eosin Methylene Blue Agar/EMBA (Oxoid, CM0069) media. Escherichia coli cultures were grown in Nutrient Broth/NB (Oxoid, CM0001) media at $37^{\circ} \mathrm{C}$ for 24 hours. Physiological $\mathrm{NaCl}$ media of $0.85 \%$ was used to dilute Escherichia coli culture results until the treatment dose was given to experimental animals - Escherichia coli bacteria at a dose of $107 \mathrm{CFU} / \mathrm{mL}$. Mice intramuscularly terminated using $0.1 \mathrm{~mL}$ of ketamine. The mice were positioned supine, i.e., the stomach was upwards and placed on the operating table. Before the surgery, the mice's abdomen give antiseptic using $70 \%$ alcohol then the spleen, liver, and uterus were taken and released from the surrounding connective tissue.

The pour plate method was used to examine the colonization of Escherichia coli bacteria; samples of the spleen, liver, and uterus were taken 0.1 gram each and ground until smooth. The mashed organs were added with $1 \mathrm{~mL}$ of NB, $1 \mathrm{~mL}$ of the organ sample solution was taken and diluted in $9 \mathrm{~mL}$ of saline $(0.9 \% \mathrm{NaCl})$. The dilution carries out three times to reduce the possibility of culture being too dense. It could interfere with the observation process. $1 \mathrm{~mL}$ suspension result was poured into a sterile petri dish. EMBA media was poured into a petri dish, the sample was tightly closed and incubated at $37^{\circ} \mathrm{C}$ for $1-2$ days. Identification of Escherichia coli would appear metallic sheen spots (glossy green) on EMBA media. A colony counter was used to count the number of the colony. Approval for this study was obtained from the Research Ethics Commission of Brawijaya University No: 003-KEP-UB-2021.

\section{Statistic analysis}

Data of the result was performed in Mean \pm SD. The calculation was performed with the SPSS for Windows software. Data analysis used one-way ANOVA test, post hoc Least Significance Different (LSD), and Pearson correlation, statistically significant if $p$-value $<0.05$.

\section{RESULTS AND DISCUSSION}

Examination of bacterial colony growth carries out using the pour plate method with EMBA media (Figure 1). The results showed that there was a decrease in the number of colonies in the liver and uterus as the dose of Rhodomyrtus tomentosa leaves ethanol extract (Rtl-EE) increased, respectively in the liver 1280 $\mathrm{CFU} / \mathrm{mL}, 924 \mathrm{CFU} / \mathrm{mL}, 330 \mathrm{CFU} / \mathrm{mL}$ and the uterus $1806 \mathrm{CFU} / \mathrm{mL}, 1180 \mathrm{CFU} / \mathrm{mL}$, $874 \mathrm{CFU} / \mathrm{mL}$. Colony growth started to decrease at dose 1 of Rtl-EE (100mg/kg BW). However, in contrast to the spleen, there was reincrease in colony growth at a dose 3 of Rtl-EE (400mg/kg BW), although the results did not exceed the positive control, 
respectively $712 \mathrm{CFU} / \mathrm{mL}, 112 \mathrm{CFU} / \mathrm{mL}, 774 \mathrm{CFU} / \mathrm{mL}$ (Figure 2). Rhodomyrtus tomentosa leaves had tested by qualitative phytochemical analysis. Results of the phytochemical analysis list are in Table 1. Qualitative phytochemical analysis showed phenols, flavonoids, saponins, tannins, alkaloids, and triterpenoids-the steroid not detected during the research.

The results of one-way ANOVA and LSD statistical tests showed a significant difference between colony growth in each organ and the observation group $(p<0.05)$ (Table 2). In addition, the Pearson correlation test uses to determine the relationship between the number of bacterial colonies and other variables. Based on the results, there was a very strong negative correlation between the number of bacterial colonies in the spleen, liver and uterus and the observation group, which was statistically significant in both groups (spleen organ; $r=-0.528, p$-value $=0.017$, liver organ; $r=-$ $0.955, p$-value $=0.000$, uterine organs; $r=-0.972, p$-value $=0.000)$ (Table 3$)$.

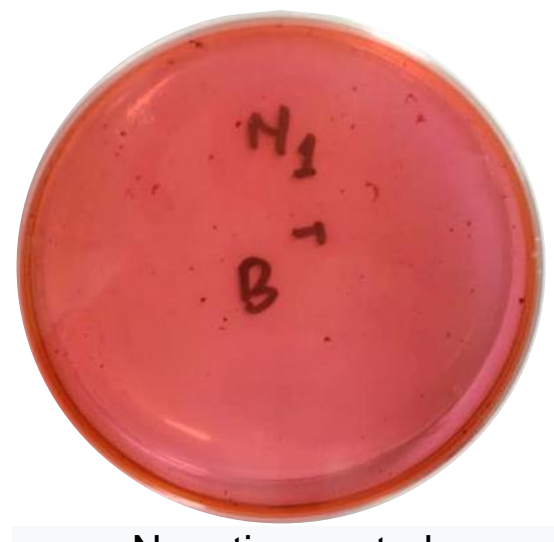

Negative control

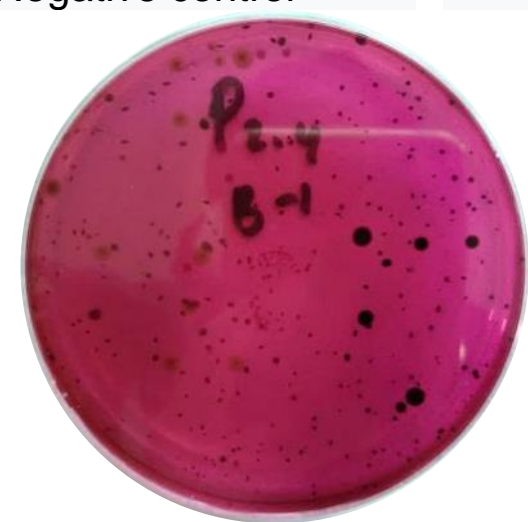

Rtl-EE II

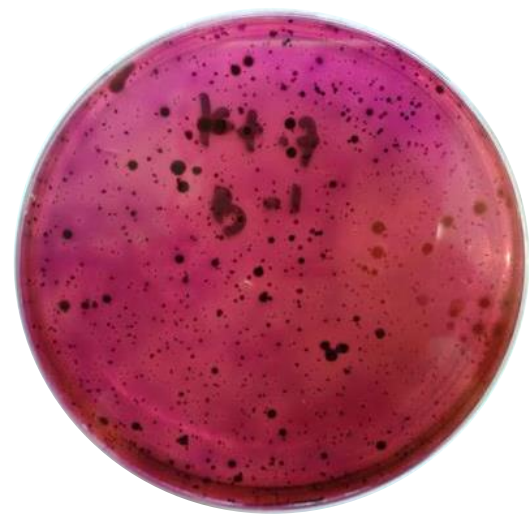

Positive control

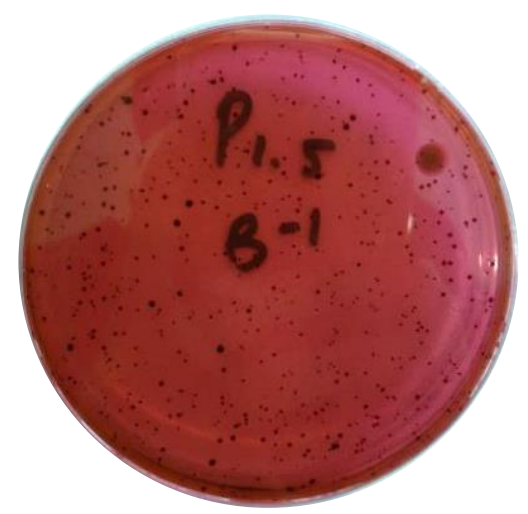

Rtl-EE I

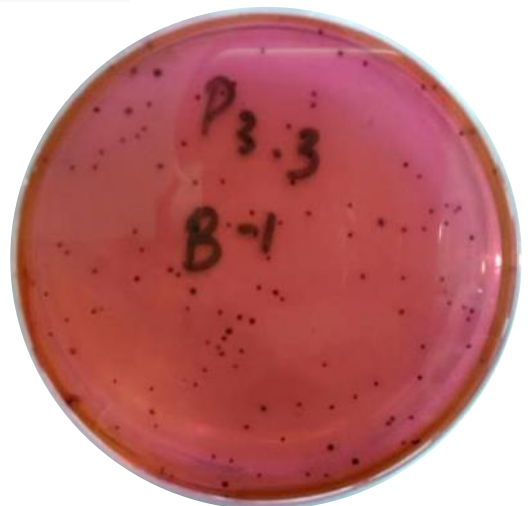

Rtl-EE III

Figure 1. Colony growth of Escherichia coli Bacteria on EMBA Medium with Various Doses of Ethanol Extract of Rhodomyrtus tomentosa Leaves $(100 \mathrm{mg} / \mathrm{kg} \mathrm{BW;200 \textrm {mg }}$ $/ \mathrm{kg} \mathrm{BW} ; 400 \mathrm{mg} / \mathrm{kg} \mathrm{BW})$. Colonies Count Using the Colony Counter. Colony Growth

Decreased with an Increasing Dose of Rhodomyrtus tomentosa Leaves Ethanol

Extract (Rtl-EE). This Result is of Culture Obtained from the Liver. 


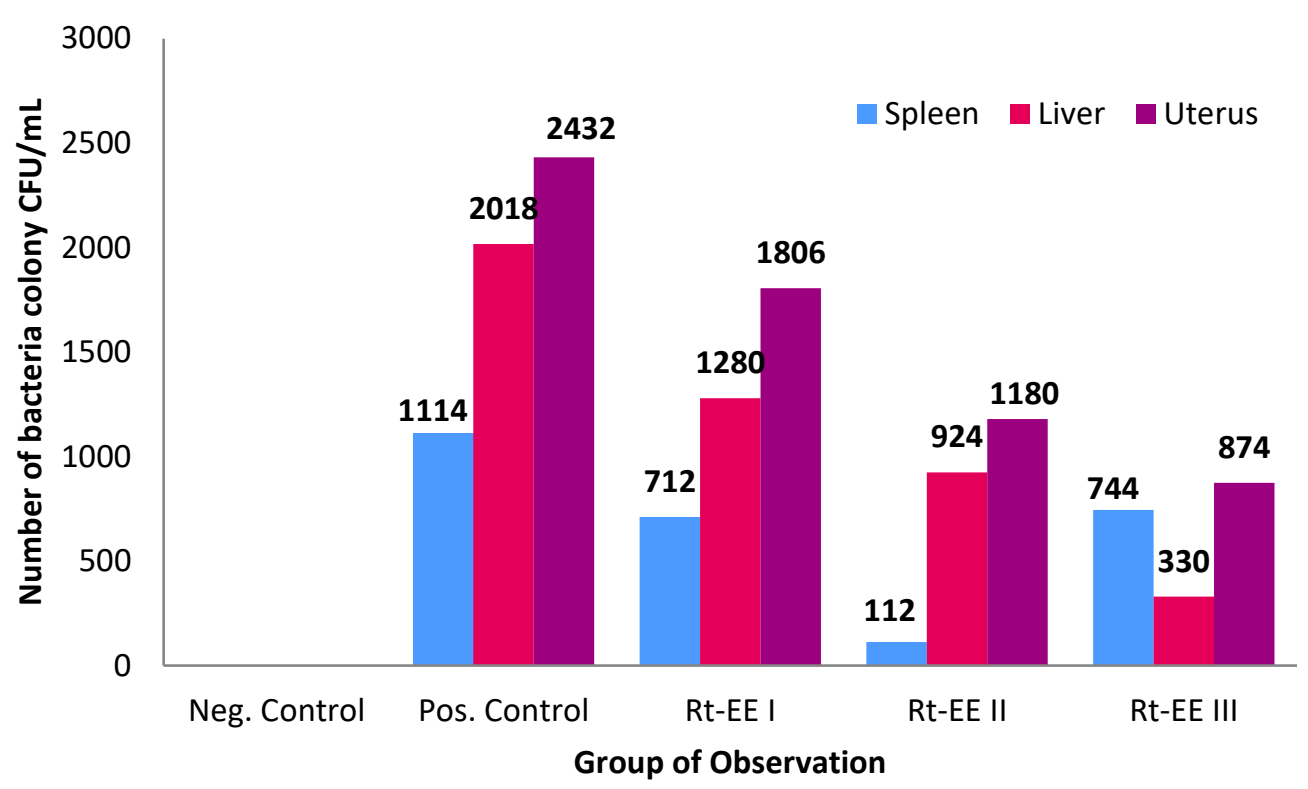

Figure 2. Histogram of Colony growth of Escherichia coli Bacteria with Various Doses of Ethanol Extract of Rhodomyrtus tomentosa Leaves $(100 \mathrm{mg} / \mathrm{kg} \mathrm{BW} ; 200 \mathrm{mg}$ $/ \mathrm{kg} \mathrm{BW} ; 400 \mathrm{mg} / \mathrm{kg} \mathrm{BW}$ ). The Ethanol Extract of Rhodomyrtus tomentosa Leaves can Reduce Bacterial Colonies in the Spleen, Liver, and Uterus.

Table 1. Phytochemical Analysis of Ethanolic Extracts of Rhodomyrtus tomentosa Leaves

\begin{tabular}{|c|c|c|c|c|}
\hline No. & Parameter & Reactor & Result & $\begin{array}{l}\text { Conclu } \\
\text { sion }\end{array}$ \\
\hline 1 & Tannins/Phenols & $\mathrm{FeCl}_{3}$ & $\begin{array}{l}\text { Dark brown, dark } \\
\text { blue }\end{array}$ & + \\
\hline 2 & Flavonoids & $\begin{array}{l}\text { Mg and concentrated } \\
\mathrm{HCl}\end{array}$ & $\begin{array}{l}\text { Orange, brick red, } \\
\text { pink, dark red }\end{array}$ & + \\
\hline 3 & Saponins & Aquadest & Permanent foam & + \\
\hline \multirow[t]{3}{*}{4} & Alkaloid & Mayer & White sediment & + \\
\hline & & Dragendrof & Orange sediment & + \\
\hline & & Bouchardat & Brown sediment & + \\
\hline 5 & Triterpenoids & $\begin{array}{c}\text { Glacial } \mathrm{CH}_{3} \mathrm{COOH} \text { and } \\
\text { concentrated } \mathrm{H}_{2} \mathrm{SO}_{4}\end{array}$ & $\begin{array}{c}\text { Orange, brownish } \\
\text { orange }\end{array}$ & + \\
\hline 6 & Steroid & $\begin{array}{c}\text { Glacial } \mathrm{CH}_{3} \mathrm{COOH} \text { and } \\
\text { concentrated } \mathrm{H}_{2} \mathrm{SO}_{4}\end{array}$ & Bluish green & - \\
\hline
\end{tabular}


Table 2. Comparison of the Average Number of Bacterial Colonies in Each Organ Based on the Observation Group

\begin{tabular}{cccc}
\hline \multirow{2}{*}{ Group } & \multicolumn{3}{c}{ Bacterial colony $(\mathrm{CFU} / \mathrm{mL})$} \\
\cline { 2 - 4 } & Spleen & Liver & Uterus \\
\hline Negative & 0 & 0 & 0 \\
Positive & $1114 \pm 105.4$ & $2018 \pm 287.2$ & $2432 \pm 109.9$ \\
RtI-EE I & $712 \pm 64.5$ & $1280 \pm 182.7$ & $1806 \pm 109.2$ \\
RtI-EE II & $112 \pm 38.3$ & $924 \pm 155.9$ & $1180 \pm 104.9$ \\
RtI-EE III & $744 \pm 61.8$ & $330 \pm 88.8$ & $874 \pm 171.6$ \\
\cline { 2 - 4 } & \multicolumn{3}{c}{$\boldsymbol{p}$-value } \\
\cline { 2 - 4 } & 0.000 & 0.000 & 0.000
\end{tabular}

${ }^{*}$ Repeated Measure ANOVA Test, with values are mean $\pm \mathrm{SD} n=5, p$-value $<0.05$ is considered significant

Table 3. Correlation Between the Observation Group with Bacterial Colony Count in Both Groups

\begin{tabular}{cccc}
\hline \multirow{2}{*}{$\begin{array}{c}\text { Bacterial colony } \\
\text { (CFU/mL) }\end{array}$} & \multicolumn{2}{c}{ Observation group } & \multirow{2}{*}{ Conclusion } \\
\cline { 2 - 3 } & $\boldsymbol{r}$-value & $\boldsymbol{p}$-value & \\
\hline Liver & -0.528 & 0.017 & Strong \\
Spleen & -0.955 & 0.000 & Very Strong \\
Uterus & -0.972 & 0.000 & Very strong \\
\hline
\end{tabular}

*Data expressed as correlation coefficient ( $r$-value) and $p$-value, $p$-value $<0.05$ is considered significant. The observation group was dependent variable.

Factors that can affect the antibacterial effectiveness consisted of compound content in bacteria, type of bacteria, and amount of extract concentration used. This result is by this research. The number of colonies in the group decreased because of a dose of ethanol extract of Rhodomyrtus tomentosa leaves extract given. Limsuwan et al. (2011) showed that Rhodomyrtus tomentosa in vitro had antibacterial activity through protein analysis in its metabolic pathway. Dwicahmi (2015) and Mordmuang and Voravuthikunchai (2015) explained that there was an antibacterial in Rhodomyrtus tomentosa that can inhibit the growth of Escherichia coli bacteria. Also, according to Indriani et al. (2019), the extract and ethanol fraction of Rhodomyrtus tomentosa (Aiton) Hassk leaves can inhibit the growth of Escherichia coli bacteria, with the best concentrations being $80 \%$ extract and $100 \%$ ethanol fraction with inhibition zones of $8.2400 \pm 1.18025$ and $8.7800 \pm 1.00100$, respectively.

However, the results of this study are not in line with Sukeri et al. (2021), who stated that no inhibition zone record at all of the methanol and aqueous extract of Rhodomyrtus tomentosa leaves obtained from the MIC assay. They suspect this may be because gram-negative bacteria are more resistant than gram-positive bacteria. The presence of a gram-negative outer membrane contributes to the persistence of bacteria to be penetrated by antibiotics. However, it is different from this study, where the study results proved that there was a decrease in the number of colonies since the administration of Rtl-EE dose 1, although there were differences in 
the results of studies on the spleen (Figure 2). In these organs, the results showed an increase of the colonies number from a dose of $200 \mathrm{mg} / \mathrm{kg} \mathrm{BW}$ (Rtl-EE II) to a dose of $400 \mathrm{mg} / \mathrm{kg} \mathrm{BW}$ (Rtl-EE III). It happened due to the presence of teratogenic and carcinogenic mutagenic effects at these doses. However, further research needs on this issue.

The decrease in the number of colonies thinks to be due to the effect of the content in the ethanolic extract of Rhodomyrtus tomentosa leaves. The content of metabolites compound could damage bacterial cells, including the flavonoid content that inhibited bacterial metabolism by disrupting the integrity of the bacterial cell membrane, thereby disrupting the growth of Escherichia coli bacteria. Alkaloid compounds interfere with the formation of bacterial cell walls by inhibiting the peptidoglycan component of bacterial cells and caused cell death (Indriani et al., 2019). Tannins targeted polypeptides on the bacterial cell wall, inactivate enzymes and interfere with the inner layer of bacteria in the course of bacterial cell proteins, which consequently could kill cells (Indriani et al., 2019). Phenol compounds could denature cell proteins and caused damage to the protein structure, which causes the metabolic process of bacteria to disrupts and bacterial cells to lyse (Dwicahmi., 2015). In addition, the content of saponin compounds could also lyse bacterial cells, and bacterial cell death occurs by disrupting membrane stability in bacterial cells (Darsana et al., 2012). The mechanism of action of triterpenoids was to cause a decrease in the permeability of bacterial cell membrane; the triterpenoid compound reacted with porin and caused damage to the porin, which use as the entrance and exit of bacteria (Dwicahmi., 2015).

The results achieved in this research were that the ethanolic extract of Rhodomyrtus tomentosa leaves had an antibacterial effect on colony growth in the spleen, liver, and uterus of the Escherichia coli -induced puerperal infection mice model so that the ethanol extract of Rhodomyrtus tomentosa leaves could be an alternative treatment for infections caused by Escherichia coli especially those caused by puerperal conditions so that it has a positive impact on reducing maternal mortality caused by the incidence of disease. However, this study had limitations; the researcher could not protect the mice infected with other bacteria before treatment because the mice obtained were not pathogen-free mice and the number of organs examined was still limited. In addition, this research only measured the phytochemical content of Rhodomyrtus tomentosa leaves qualitatively, so it was difficult to determine the dose that caused other side effects.

\section{CONCLUSION}

Rhodomyrtus tomentosa leaves ethanol extract (Rtl-EE) had an antibacterial effect by reducing the number of bacteria on the spleen, liver, and uterus of Escherichia coli-induced puerperal infection model mice. The growth of Escherichia coli bacteria decreased after the administration of Rtl-EE dose, the decrease of Escherichia coli in the liver and uterus started at a quantity of $1 \mathrm{Rtl}-\mathrm{EE}(100 \mathrm{mg} / \mathrm{kg}$ BW), and the lowest was at a dose of 3 Rtl-EE (400mg/kg BW), Decreases in the liver were $1280 \mathrm{CFU} / \mathrm{mL}, 924 \mathrm{CFU} / \mathrm{mL}, 330 \mathrm{CFU} / \mathrm{mL}$ and uterus $1806 \mathrm{CFU} / \mathrm{mL}, 1180$ $\mathrm{CFU} / \mathrm{mL}, 874 \mathrm{CFU} / \mathrm{mL}$, respectively. However, in contrast to the spleen, there was a decrease in the dose of $1 \mathrm{Rtl}-\mathrm{EE}(100 \mathrm{mg} / \mathrm{kg} \mathrm{BW})$, and colony growth increased at a quantity of $3 \mathrm{Rtl}-\mathrm{EE}(400 \mathrm{mg} / \mathrm{kg} \mathrm{BW})$, although the results did not exceed the positive control, respectively $712 \mathrm{CFU} / \mathrm{mL}, 112 \mathrm{CFU} / \mathrm{mL}, 774 \mathrm{CFU} / \mathrm{mL}$. Therefore, the researcher suggests further research must be conducted to examine the toxic dose of Rhodomyrtus tomentosa leaves against Escherichia coli bacteria. 


\section{ACKNOWLEDGEMENT}

The author would like to thank the Domestic Postgraduate Education Scholarship (BPPDN)-Afirmasi, which has assisted the process of funding this research. The author would also like to thank all parties supporting and facilitating the research process and journal publication.

\section{CONFLICT OF INTEREST}

All authors state that there is no conflict or problem with any party in the writing of this journal publication.

\section{REFERENCES}

Boushra, M., \& Rahman, O. (2020). Postpartum Infection. StatPearls Publishing.

Cunningham, F. G., Leveno, K. J., Bloom, S. L., Hauth, J., Rouse, D., \& Spong, C. Y. (2010). Puerperal Infection. In Williams Obstetrics 23rd Edition. Mc Graw Hill Co.

Darsana, I. G. O., Besung, I. N. K., \& Mahatmi, H. (2012). The Potential of Binahong Leaves (Anredera Cordifolia (Tenore) Steenis) in Inhibiting the Growth of Escherichia coli Bacteria, Indonesia Medicus Veterinus, 1(3).

Dwicahmi, P. (2015). Antibacterial activity test of $70 \%$ ethanol extract of karamunting (Rhodomyrtus tomentosa (Ait.) Hassk) leaves on the growth of Vibrio cholerae bacteria in vitro, Tanjungpura Pontianak University.

Harlia Erika Juniar, A. H. A. (2017). Cytotoxic and Antioxidant Activity of Karamunting Stem Extract (Rhodomyrtus Tomentosa (Aiton) Hassk), Journal of Equatorial Chemistry, 6(2), pp. 37-43.

Haruna, N. (2017). Mother's knowledge and attitude about prevention and control of puerperal infection in Bella Bori and Bella Punranga, Regency of Gowa, Experience Journal, 1(1), pp. 67-69.

Hilda and Berliana. (2015), Patterns of resistance of staphylococcus aureus, escherichia coli, pseudomonas aeruginosa bacteria to various antibiotics in the Health Laboratory of East Kalimantan Province in 2013, Journal of Laboratory Technology,4(2).

Indriani, O., Fatiqin, A., \& Oktarina, T. (2019). Effect of Extract and Fraction of Karamunting leaves (Rhodomyrtus tomentosa (Aiton) Hassk.) on the Growth of Escherichia coli Bacteria, Jurnal Aisyiyah Medika, 4(3).

Ismandari, T., Kumalaningsih, S., Wijana, S., \& Mustaniroh, S. A. ul. (2020). Optimization of Bioactive Compound Extraction from Rose Myrtle Fruit (Rhodomyrtus tomentosa, (W.Ait), Myrtaceae) as the Antioxidant Source, Scientific World Journal.

Limsuwan, S., Hesseling-Meinders, A., Voravuthikunchai, S. P., van Dijl, J. M., \& Kayser, O. (2011). Potential antibiotic and anti-infective effects of rhodomyrtone from Rhodomyrtus tomentosa (Aiton) Hassk. on Streptococcus pyogenes as revealed by proteomics, Phytomedicine, 18(11), 934-940.

Marni. (2012). Midwifery Care in Childbirth. Yogyakarta: Student Library.

Megawati, E. P., Khotimah, S., \& Bangsawan, P. I. (2016). Antifungal Activity Test of Karamunting leaves (Rhodomyrtus tomentosa) Ethanol Extract Against the Growth of Candida Albicans In Vitro, Students Journal PSPD FK Tanjungpura University.

Mochtar R, dan S. A. (2012). inopsis Obstetri: Obstetri Fisiologi Obstetri Patologi Edisi III. EGC.

Mordmuang, A., \& Voravuthikunchai, S. P. (2015). Rhodomyrtus tomentosa (Aiton) Hassk. leaf extract: An alternative approach for the treatment of staphylococcal 
bovine mastitis, Research in Veterinary Science, 102, 242-246.

Pascual, L., Ruiz, F., Giordano, W., \& Barberis, I. L. (2010). Vaginal colonization and activity of the probiotic bacterium Lactobacillus fermentum L23 in a murine model of vaginal tract infection, Journal of Medical Microbiology, 59(3), 360-364.

Sáez-López, E., Guiral, E., Fernández-Orth, D., Villanueva, S., Goncé, A., López, M., Teixidó, I., Pericot, A., Figueras, F., Palacio, M., Cobo, T., Bosch, J., \& Soto, S. M. (2016). Vaginal versus Obstetric Infection Escherichia coli Isolates among Pregnant Women: Antimicrobial Resistance and Genetic Virulence Profile, PLoS One, 11(1).

Saising, J., Ongsakul, M., \& Voravuthikunchai, S. P. (2011). Rhodomyrtus tomentosa (Aiton) Hassk. ethanol extract and rhodomyrtone: a potential strategy for the treatment of biofilm-forming staphylococci, Journal of Medical Microbiology, 60(Pt 12), 1793-1800.

Senthilmurugan G, Vasanthe B, Suresh K. (2013). Screening and antibacterial activity analysis of some important medicinal plants, IntI J Innov Appl Stud 2: 146-152.

Song, H., Hu, K., Du, X., Zhang, J., \& Zhao, S. (2020). Risk factors, changes in serum inflammatory factors, and clinical prevention and control measures for puerperal infection, Journal of Clinical Laboratory Analysis, 34(3), 1-7.

Sukeri, S., Karem, A.A., Kamarudin, E. and Bahari, M., (2021). Antimicrobial Activity of Methanolic and Aqueous Extract of Rhodomyrtus tomentosa Leaves against Staphylococcus aureus and Escherichia coli, J Pure Appl Microbiol, 15(1), pp186-19.

Wardhani, R. K., Sumarno, \& Endharti, A. T. (2017). Effect of probiotic lactobacillus reuteri on the percentage of regulatory cells and T helper cells 22 in the spleen of puerperal mice induced by Staphylococcus aureus bacteria, Journal of Issues in Midwifery, 1(3), pp. 18-29. 